\title{
Role of Farmers in Vertical Coordinated Vegetable Supply Chains in Odisha
}

\author{
Dr. Uma Shankar Singh \\ Faculty of Administrative Sciences and Economics, Tishk International University, Erbil-Kurdistan
}

\begin{abstract}
Farmers are always struggling with many challenges in the absence of well-developed support systems. The opinion of farmer and intermediaries are very important to reach the conclusion, so an assessment has been performed measuring the similarities and differences in opinion based on defined factors considered as the key success factors and constraints to participate in the vertically coordinated vegetable supply chain. Horticulture is one of the most growing sectors with ample opportunities throughout the state helping in development of economic situations of farmer's by getting the cash on produce sales. The producer's participation in vegetable supply chain has been analyzed on the basis of data collected as the sample considering the well representative of the whole population. The samples collected from three districts of Odisha namely Bhubaneswar/ Khorda, Puri and Balasore with the frequency of 250, 279 and 228 respectively, which is $33.0 \%, 36.9 \%$ and $30.1 \%$ respectively. This paper importantly mentioning the overview of the Odisha and the supply chain for vegetables, characteristics of producers and intermediaries participating in VCVSC (producer's characteristics and intermediary's characteristics) and the market participation of farmers and intermediaries in the VCVSC.
\end{abstract}

Keywords: VCVSC, vegetable, vertical coordinated, supply chain, Odisha

DOI: $10.7176 / \mathrm{FSQM} / 87-06$

Publication date:May $31^{\text {st }} 2019$

\section{Introduction}

The role of farmers in vertically coordinated vegetable supply chain for the development and benefit of all stakeholders is the foremost important concern that can suggest a healthy supply chain. A comparative analysis with the different aspects of the identified main market channels with different ways and level of participation of stakeholder are discussed Mehakud, P. K. (1997). Opportunities and threats to the farmers and intermediaries always bring some advantages and challenges in each channel. Here, the discussion is about all the channels characterizing social and economic values that create the psychological strength among the stake holders and organizations (Mallick, S. C, 1987). Odisha is privileged with natural diversity that provides different climatic zones suitable for different kind of vegetables. The state has a huge opportunity for farmers to participate in vegetable production and can improve their economic and social condition. The ranking of different vegetables in the state with contribution with the variation in the modes of supply chain vegetable in different districts of the state is presented. Role of government and the privately developed system to support the supply chain has an impact on farmers and intermediaries business model Mohapatra, S. C. (1999). Farmers are always struggling with many challenges in the absence of well-developed support systems.

The gap in information and storage of produce kill the price for farmers produce and does not provide them sufficient returns (Mohapatra, B. K., 2001). At this stage now the state needs a well-developed marketing model and the agricultural produce marketing organization that can develop a system to monitor and control the execution (Naik, D. and D. N. Singh, 2006). Advantages and Challenges associated with the vertically coordinated vegetable supply chain is the main concern and another is the problems in implementing market regulation Nayak, S. R. (2008). The opinion of farmer and intermediaries are very important to reach the conclusion, so an assessment has been performed measuring the similarities and differences in opinion based on defined factors considered as the key success factors and constraints to participate in the vertically coordinated vegetable supply chain. Further this has been conceptually justified and analytically explained with the concluding statement.

\section{Overview of the Odisha and the Supply Chain for Vegetables}

Odisha has a variety of climatic conditions supporting to agriculture and allied industry. Horticulture is one of the most growing sectors with ample opportunities throughout the state helping in development of economic situations of farmer's by getting the cash on produce sales. Odisha state is the cultivator of many short term vegetables favored by climatic condition. The cultivation is distributed in state on the basis of climatic condition throughout the state explained by NIAM (2005). Specially the off season vegetables are available in Phulbani \& Keonjhar districts. In the ranking of vegetable production the Odisha state gets the fourth rank in India having variety of vegetables almost all grown in India by NSSO (2005). The cultivation of vegetables are divided in two seasons mainly summer crops and winter crops. The domestic consumption for vegetables in the state is highest compared to other states in the country by Panigrahi, H. S. (2008). Many other vegetables are grown throughout 
the year in the state are Brinjal, Bhindi, Cucumber, Watermelon and Gourds. Many off season vegetables are produced in Koraput, Keonjhar, Gajapati and Khandamal districts having the rich availability of vegetables throughout the year and support the export as well. Potatoes, watermelon, Onion, Gourd are important vegetables among vegetables cultivated with huge water resources during both winter and summer (RCDC, 2011). The state itself is sufficient in fulfilling the demand of its population for vegetables with the production capacity during different season. For the development of agricultural sector in the state there is a strong need for a proven model of agricultural marketing stated by Sahu H.K. and S. Thipathi (1998). Since, the global integration in agricultural sector is taking place, so it is more being market driven rather produce driven. As per the report of The Royal commission on Agriculture (1928) the agricultural classes of India are getting affected due to the defects of marketing practices, so the agricultural marketing system remove its drawbacks and develop a wellstructured agricultural marketing system. The present status of state as per this study is presented further. A study by World Bank has presented a schematic diagram summarizing the current flow of agricultural marketing system in Odisha getting regulated and controlled by Regulated Market Committees (Seth, B. N. , 2010; Singh, Alka, A. K. Vasisth, B. R. Atteri and D. Singh., 2004; Vasundhara., 2005; Vaswani, L. K., P. K. Das, P. K. Parida and Tapas Mandal., 2011). The most percentage of the surplus produce is marketed by the Regulated Market Committees (Sarangi, K. K., 2009). The study conducted by Vaswani et. al. on the vegetable marketing system in Odisha suggests the following common channels are participating in supply chain.

(A) Farmers - Local traders - Traders/ Wholesalers - Retailers - Consumers

(B) Farmers - Traders/ Wholesalers - Retailers - Consumers

(C) Farmers - Retailers - Consumers

(D) Farmers - Consumers

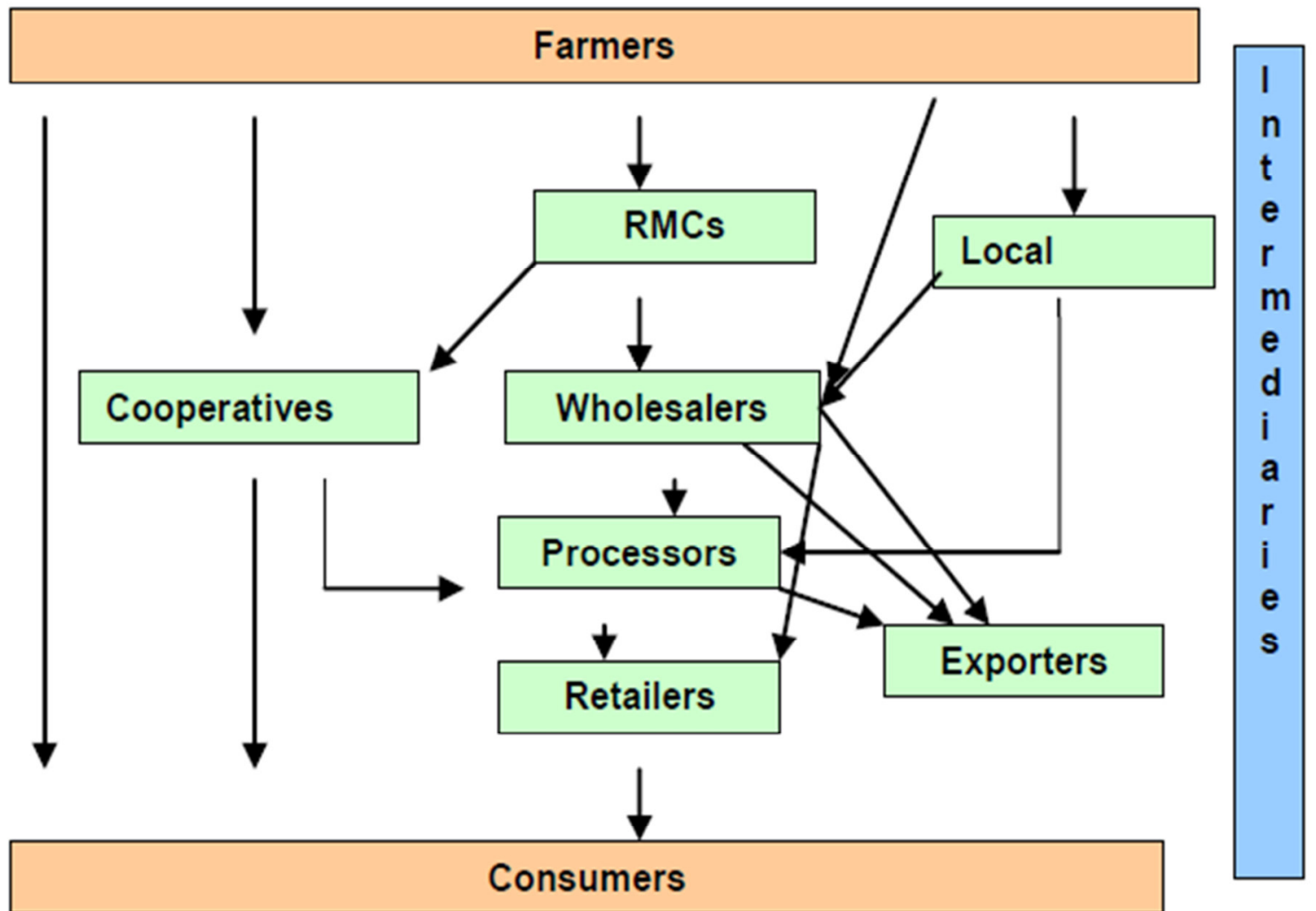

Agricultural Marketing Channels in Odisha

Fig.1 Agricultural Marketing Channel in Odisha 
Table 1.1: Characteristics of Producers in Vertical Coordinated Vegetable Supply Chains

\begin{tabular}{|l|l|c|c|}
\hline \multicolumn{2}{|c|}{ Parameters } & Frequency & Percentage \\
\hline Location & Bhubaneswar/ Khorda & 250 & 33.0 \\
& Puri & 279 & 36.9 \\
& Balasore & 228 & 30.1 \\
\hline Gender & Male & 605 & 79.9 \\
& Female & 152 & 20.1 \\
\hline No. of People Engaged Full Time in Vegetable & 1Member - 3Member & 474 & 62.6 \\
Farming & 4 Member - 6 Member & 283 & 37.4 \\
\hline No. of People Engaged Part Time in Vegetable & 1Member - 3Member & 384 & 50.7 \\
Farming & 4 Member - 6 Member & 62 & 8.2 \\
& 7 Member - 9 Member & 311 & 41.1 \\
\hline No. of Hired Non Family Labour & 1Member - 3Member & 451 & 59.6 \\
& 4 Member - 6 Member & 306 & 40.4 \\
\hline Annual Earning of the Family & Rs.1 - Rs.20,000 & 747 & 98.7 \\
& Rs.21,000 - Rs.30,000 & 10 & 1.3 \\
\hline Duration of Vegetable Business Startup & Between 3 Years - 6 Years & 142 & 18.8 \\
& 6 Years and more & 615 & 81.2 \\
\hline Role in Vegetable Supply Chain & Farmers with Small Land & 619 & 81.8 \\
& Holding & & 18.2 \\
\hline
\end{tabular}

The producer's participation in vegetable supply chain has been analyzed on the basis of data collected as the sample considering the well representative of the whole population. The samples collected from three districts of Odisha namely Bhubaneswar/ Khorda, Puri and Balasore with the frequency of 250, 279 and 228 respectively, which is $33.0 \%, 36.9 \%$ and $30.1 \%$ respectively. This represents that the data is collected almost equally from the three districts. The Gender distribution is Male and Female as 605 and 152 which is $79.9 \%$ and $20.1 \%$, shows the females participation in agriculture is much lesser than the males. The two categories presented in No. of People Engaged Full Time in Vegetable Farming as 1Member - 3Member and 4 Member - 6 Member shows the frequency of 474 and 283 which is 62.6 and 37.4 respectively, shows very less number of people from the family are engaged full time in agriculture. No. of People Engaged Part Time in Vegetable Farming category talks about three different parameters are 1Member - 3Member, 4 Member - 6 Member and 7 Member - 9 Member showing the frequency of 384, 62 and 311 with 50.7\%, 8.2\% and 41..1\% respectively creates a picture that either very less people or almost all the people work as part time in the field rather mid number of people do not go as part time work in agriculture. The next analysis is about the No. of Hired Non Family Labor having categories 1Member - 3Member and 4 Member - 6 Member with frequency of 451 and 306 which is $59.6 \%$ and $40.4 \%$ respectively. Annual Earning of the Family has categories as Rs. 1 - Rs.20,000 and Rs.21,000 - Rs.30,000 gets the frequency of 747 and 10 which is 98.7 and 1.3 respectively shows people engaged in vegetable farming having very less earnings. Duration of Vegetable Business Startup is measuring the vegetable cultivation experience of the respondents with categories Between 3 Years - 6 Years and 6 Years and more gets the frequency of 142 and 615 i.e. $18.8 \%$ and $81.8 \%$ respectively shows that farmers are engaged in vegetable farming since years. The last is the Role in Vegetable Supply Chain has categories as Farmers with Small Land Holding and Farmers with Sufficient Land Holding with frequency of 619 and 138 and percentage of $81.8 \%$ and $18.2 \%$ shows that most of the respondents are with small farm holding. 
Table 1.2: Market Participation of Farmers in the Vertical Coordinated Vegetable Supply Chains: T-Test to Marketing Participation for Producer

\begin{tabular}{|c|c|c|c|c|c|c|}
\hline \multicolumn{7}{|c|}{ One-Sample Test } \\
\hline & \multicolumn{6}{|c|}{ Test Value $=4$} \\
\hline & \multirow[b]{2}{*}{$\mathrm{t}$} & \multirow[b]{2}{*}{ df } & \multirow{2}{*}{$\begin{array}{l}\text { Sig. }(2- \\
\text { tailed) }\end{array}$} & \multirow{2}{*}{$\begin{array}{c}\text { Mean } \\
\text { Difference }\end{array}$} & \multicolumn{2}{|c|}{$\begin{array}{l}95 \% \text { Confidence } \\
\text { Interval of the } \\
\text { Difference }\end{array}$} \\
\hline & & & & & Lower & Upper \\
\hline Proportion of Vegetable Produce sold to Consumer (at farm) & 79.807 & 756 & .000 & 18.840 & 18.38 & 19.30 \\
\hline Proportion of Vegetable Produce sold to Consumer (at local market) & 97.702 & 756 & .000 & 15.802 & 15.48 & 16.12 \\
\hline Proportion of Vegetable Produce sold to Middlemen (at farm) & 88.824 & 756 & .000 & 21.905 & 21.42 & 22.39 \\
\hline $\begin{array}{l}\text { Proportion of Vegetable Produce sold to Middlemen (at local } \\
\text { market) }\end{array}$ & 332.491 & 756 & .000 & 27.453 & 27.29 & 27.62 \\
\hline $\begin{array}{l}\text { Proportion of Vegetable Produce sold } 5 \text { Years Ago to Consumer (at } \\
\text { farm) }\end{array}$ & 68.741 & 756 & .000 & 21.885 & 21.26 & 22.51 \\
\hline $\begin{array}{l}\text { Proportion of Vegetable Produce sold } 5 \text { Years Ago to Consumer (at } \\
\text { local market) }\end{array}$ & 72.251 & 756 & .000 & 23.034 & 22.41 & 23.66 \\
\hline $\begin{array}{l}\text { Proportion of Vegetable Produce sold } 5 \text { Years Ago to Middlemen } \\
\text { (at farm) }\end{array}$ & 43.224 & 756 & .000 & 16.727 & 15.97 & 17.49 \\
\hline $\begin{array}{l}\text { Proportion of Vegetable Produce sold } 5 \text { Years Ago to Middlemen } \\
\text { (at local market) }\end{array}$ & 81.611 & 756 & .000 & 22.354 & 21.82 & 22.89 \\
\hline $\begin{array}{l}\text { Proportion of Vegetable Produce sold } 5 \text { Years Ago to Supermarket } \\
\text { (at farm) }\end{array}$ & 81.544 & 756 & .000 & 1.929 & 1.88 & 1.98 \\
\hline $\begin{array}{l}\text { Proportion of Vegetable Produce sold } 5 \text { Years Ago to Supermarket } \\
\text { (at market) }\end{array}$ & 81.544 & 756 & .000 & 1.929 & 1.88 & 1.98 \\
\hline Proportion of Vegetable Produce sold 5 Years Ago to Others & 81.544 & 756 & .000 & 1.929 & 1.88 & 1.98 \\
\hline Distance from Farm to Consumer (at farm) & -201.422 & 756 & .000 & -2.967 & -3.00 & -2.94 \\
\hline Distance from Farm to Consumer (at local market) & -228.637 & 756 & .000 & -2.863 & -2.89 & -2.84 \\
\hline Distance from Farm to Middlemen (at farm) & -139.845 & 756 & .000 & -2.536 & -2.57 & -2.50 \\
\hline Distance from Farm to Middlemen (at local market) & 8.751 & 756 & .000 & .415 & .32 & .51 \\
\hline Distance from Farm to Supermarket (at farm) & -56.837 & 756 & .000 & -3.380 & -3.50 & -3.26 \\
\hline Distance from Farm to Supermarket (at market) & 54.648 & 756 & .000 & 55.709 & 53.71 & 57.71 \\
\hline Distance from Farm to Others & 5.489 & 756 & .000 & 4.692 & 3.01 & 6.37 \\
\hline Frequency to Sell Vegatable Produce & -4.839 & 756 & .000 & -.263 & -.37 & -.16 \\
\hline Frequency 5 Years Ago to Sell Vegatable Produce & 17.430 & 756 & .000 & .287 & .25 & .32 \\
\hline To Choose the market Importance of Level of Market Prices & -138.927 & 756 & .000 & -2.288 & -2.32 & -2.26 \\
\hline To Choose the market Importance of Variability of Market Prices & -143.082 & 756 & .000 & -2.248 & -2.28 & -2.22 \\
\hline To Choose the market Importance of Level of Market Demand & 10.209 & 755 & .000 & .175 & .14 & .21 \\
\hline To Choose the market Importance of Variability of Market Demand & -509.786 & 756 & .000 & -2.974 & -2.99 & -2.96 \\
\hline To Choose the market Importance of Specific Products Demanded & 33.380 & 756 & .000 & .596 & .56 & .63 \\
\hline To Choose the market Importance of Grading Requirements & -33.380 & 756 & .000 & -.596 & -.63 & -.56 \\
\hline To Choose the market Importance of Access to Information & -33.380 & 756 & .000 & -1.192 & -1.26 & -1.12 \\
\hline To Choose the market Importance of Frequency of Selling & -145.437 & 756 & .000 & -2.596 & -2.63 & -2.56 \\
\hline To Choose the market Importance of Place of Selling & -42.146 & 756 & .000 & -1.403 & -1.47 & -1.34 \\
\hline To Choose the market Importance of Payment Mechanism & -5.366 & 756 & .000 & -.192 & -.26 & -.12 \\
\hline To Choose the market Importance of Costs to Enter market & -36.506 & 756 & .000 & -1.914 & -2.02 & -1.81 \\
\hline $\begin{array}{l}\text { To Choose the market Importance of Need for Producer } \\
\text { Organization }\end{array}$ & -36.506 & 756 & .000 & -1.914 & -2.02 & -1.81 \\
\hline To Choose the market Importance of Cost of Transportation & -34.892 & 756 & .000 & -1.851 & -1.95 & -1.75 \\
\hline To Choose the market Importance of Ease of Transportation & -34.892 & 756 & .000 & -1.851 & -1.95 & -1.75 \\
\hline Contract Compared to Traditional Marketing of Vegetable & -134.705 & 756 & .000 & -2.404 & -2.44 & -2.37 \\
\hline
\end{tabular}

The 35 items selected to measure the level of marketing participation by farmers are proportion of vegetable produce sold to consumer (at farm), proportion of vegetable produce sold to consumer (at local market), proportion of vegetable produce sold to middlemen (at farm), proportion of vegetable produce sold to middlemen (at local market), proportion of vegetable produce sold 5 years ago to consumer (at farm), proportion of vegetable produce sold 5 years ago to consumer (at local market), proportion of vegetable produce sold 5 years ago to middlemen (at farm), proportion of vegetable produce sold 5 years ago to middlemen (at local market), proportion of vegetable produce sold 5 years ago to supermarket (at farm), proportion of vegetable produce sold 5 years ago to supermarket (at market), proportion of vegetable produce sold 5 years ago to others, distance from farm to consumer (at farm), farm to consumer (at local market), distance from farm to middlemen (at farm), distance from farm to middlemen (at local market), distance from farm to supermarket (at farm), distance from farm to supermarket (at market), distance from farm to others, frequency to sell vegetable produce, frequency 5 years ago to sell vegetable produce, to choose the market importance of level of market prices, to choose the market importance of variability of market prices, to choose the market importance of level of market demand, to choose the market importance of variability of market demand, to choose the market importance of specific products demanded, to choose the market importance of grading requirements, to choose the market importance of access to information, to choose the market importance of frequency of selling, to choose the 
market importance of place of selling, to choose the market importance of payment mechanism, to choose the market importance of costs to enter market, to choose the market importance of need for producer organization, to choose the market importance of cost of transportation, to choose the market importance of ease of transportation and contract compared to traditional marketing of vegetable. By Fafchamp (2006); Vasundhara (2005) and Das (2006), All 35 showed the significant value, interprets that there is significant difference in opinion and producers are willing to participate in vertically coordinated vegetable supply chain for vegetables.

\section{Conclusion}

This paper importantly mentioning the overview of the Odisha and the supply chain for vegetables, characteristics of producers and intermediaries participating in VCVSC (producer's characteristics and intermediary's characteristics) and the market participation of farmers and intermediaries in the VCVSC. During the presentation of the first segment overview of the Odisha and the supply chain for vegetables the share of five vegetables has been shown which are taken in this study and the others grown in Odisha. The five vegetables taken are namely brinjal, cabbage, cauliflower okra, peas, tomato, onion, potato, sweet potato and all the other vegetables together based on area of cultivation and production. The second segment has well presented the characteristics of producers and intermediaries participating in VCVSC (producer's characteristics and intermediary's characteristics) explain the demographic profile and their participation activities. The third part is the presenter of the market participation of farmers in the VCVSC, and It is presented with 35 items having the complete picture of farmers and intermediaries opinion.

\section{Reference}

Baecke, E., Rogiers, G., Cock, L. D. \& Huylenbroeck, G., V. (2002). The supply chain and conversion to organic farming in Belgium or the story of the egg and the chicken. British Food Journal, 104(3), 163-174.

Baourakis, G., Kourgiantakis, M. \& Migdalas, A. (2002). The impact of e-commerce on agro-food marketing: The case of agricultural cooperatives, firms and consumers in Crete. British Food Journal, 104(8), 580-590.

Cadilhon, J., J., Fearne, A., P., Moustier, P., \& Poole, N., D. (2003). Modelling vegetable marketing systems in South East Asia: phenomenological insights from Vietnam. Supply Chain Management: An International Journal, 8(5), 427-441.

Du, X., F., Leung, S., C., H., Zhang, J., L., \& Lai, K. K. (2009). Procurement of agricultural products using the CPFR approach. Supply Chain Management: An International Journal, 14(4), 253258.

Gong, W., Parton, K., Cox, R., J., \& Zhou, Z. (2006). Transaction costs and cattle farmers' choice of marketing channels in China: A Tobit analysis. Management Research News, 30(1), 47-56.

Gunderson, M. A.., Detre, J. D., Briggeman, B. C., \& Wilson, C. A. (2011). Ag lending: the next generation. Agricultural Finance Review, 71(3), 280-294.

Hamdar, B. C. (1999). A new era for efficient food manufacturing in the Lebanon: the experience of Conserves Modernes Chtaura. Supply Chain Management: An International Journal, 4(1), 14-17.

Kalusopa, T. (2005). The challenges of utilizing information communication technologies (ICTs) for the smallscale farmers in Zambia. Library Hi Tech, 23(3), 414-424.

Karimi, A. \& Malekmohamadi, I. (2011). A conceptual model of intrapreneurship in the Iranian agricultural extension organization Implications for HRD. Journal of European Industrial Training, 35(7), 632-657.

Kiplangat, J. (1999). An analysis of the opportunities for information technology in improving access, transfer and the use of agricultural information in the rural areas of Kenya. Library Management, 20(2), 115-128.

Laoubi, K \& Yamao, M. (2009). A typology of irrigated farms as a tool for sustainable agricultural development in irrigation schemes: The case of the East Mitidja scheme, Algeria. International Journal of Social Economics, 36(8), 813-831.

Loader, R. (1997). Assessing transaction costs to describe supply chain relationships in agri-food systems. Supply Chain Management: An International Journal, 2(1), 23-35.

Lwoga, E.T., Stilwell, Christine, S. \& Ngulube P. (2011). Access and use of agricultural information and knowledge in Tanzania. Library Review, 60(5), 383- 395.

McElwee, G., Anderson, A., \& Vesala, K. (2006). The strategic farmer: a cheese producer with cold feet?. Journal of Business Strategy, 27(6), 65-72.

Mehakud, P. K. (1997). Production and Marketing of Vegetables in Sadar Block of Keonjhar district", M. Sc. Agricultural Economics Thesis submitted to OUAT, Bhubaneswar (unpub.).

Menexes, G., Angelopoulos, S. (2008). Proposals for the financing and development of Greek farms based on a clustering method for categorical data. EuroMed Journal of Business, 3(3), 263-285.

Miles, M., P., White, J., B., \& Munilla, L., S. (1997). Strategic planning and agribusiness: an exploratory study of the adoption of strategic planning techniques by co-operatives. British Food Journal, 99(11), 401-408.

Mohapatra, B. K. (2001). "Marketing of Potato in Jagatsinghpur District", M. Sc. Agricultural Economics Thesis submitted to OUAT, Bhubaneswar (unpub.). 
Naik, D. \& Singh, D. N. (2006). Marketing of vegetables in rural markets of koraput district in Orissa: a micro level analysis. Jn. Res. Orissa Univ. Agric. Tech, 24(1), 108-117.

Ocran, M. K., \& Biekpe, N. (2008). Agricultural commodity supply response in Ghana. Journal of Economic Studies, 35(3), 224-235.

Oduwole, A. A., \& Okorie C. N. (2010). Access to agricultural information and millennium development goals. Library Hi Tech News, 27(1), 10-12.

Renko, N., Nikolasevic, S., \& Pavicic, J. (2002). The market information system and state support for the market of agricultural products in Croatia. British Food Journal, 104(7), 543-571.

Tamilia, R. D., \& Charlebois, S. (2007). The importance of marketing boards in Canada: a twenty-first century perspective. British Food Journal, 109(2), 119-144.

Thapisa, A.P.N. (1997). A quest for an agricultural information programme for Southern Africa. Library Management, 18(4), 196-204.

Vaswani, L. K., Das, P. K., Parida, P. K. \& Mandal, T. (2011). Study of Vegetable Marketing System in Earstwhile Cuttack and Puri Districts in Orissa", Report submitted to OSAMB by KIIT School of Rural Management, Bhubaneswar.

Velev, M. S. \& Marinov, I. T. (2004). Research of Bulgarian companies marketing effectiveness, Managerial Auditing Journal, 19(6), 774-789.

Vesala, K. M., Peura, J. \& McElwee, G. (2007). The split entrepreneurial identity of the farmer. Journal of Small Business and Enterprise Development, 14(1), 48-63.

Walley, K., Custance, P., Taylor, S., Lindgreen, A., \& Hingley, M. (2007). The importance of brand in the industrial purchase decision: a case study of the UK tractor market. Journal of Business \& Industrial Marketing, 22(6), 383-393.

White, J. B. (1997). An exploratory study into the adoption of capital budgeting techniques by agricultural cooperatives. British Food Journal, 99(4), 128-132.

Zhang, G., \& Lane, D. M. (2001). Best English language Web sites in agriculture from an international perspective. The Electronic Library, 19(1), 37-42. 